\title{
Government Solvency: Revisiting some EMU Countries
}

\author{
Michael G. Arghyrou \\ Department of Economics and Finance \\ Brunel University, Uxbridge, UB8 3PH \\ Tel: + 1895203179 \\ Michael.Arghyrou@brunel.ac.uk \\ and \\ Kul B Luintel* \\ Department of Economics and Finance \\ Brunel University, Uxbridge, UB8 3PH \\ Tel: + 1895783717 \\ E-mail: Kul.Luintel@brunel.ac.uk
}

\begin{abstract}
Corsetti and Roubini (1991) reported that the government finances of Greece, Ireland, Italy and the Netherlands did not satisfy the intertemporal budget constraint (IBC). We re-examine this issue by utilizing a new empirical approach and extended data set. Structural shifts, an issue which Corsetti and Roubini were unable to address due to the lack of suitable econometric methods, are tackled. We show that: (i) government finances of all four countries satisfy the IBC and this finding is robust to different time horizons; (ii) multiple structural shifts, most of which correspond to important policy changes, did occur in the fiscal path of these countries; and (iii) the overall effect of structural shifts has been to strengthen the evidence supporting IBC. We also find a clear positive Maastricht effect on IBC.
\end{abstract}

Key words: Intertemporal budget constraints; Strong and weak form sustainability; Structural breaks.

JEL Classification: E60; F41: N10

* Corresponding author 


\section{Introduction}

Whether or not government deficit and debt are sustainable if continued at the present rate (i.e., if government budget is balanced in present-value terms) is an important policy issue. Compliance of intertemporal budget constraint (IBC) implies that government is not resorting to ponzi schemes i.e., systematic financing of maturing old debt by issuing new one. Hamilton and Flavin (1986) is perhaps one of the earliest attempts to derive and test for the government's IBC. Using annual data spanning 1962-1984, they report that US government finances satisfied the IBC. Subsequently, a voluminous literature mainly examining the US public finances has evolved; however studies on other economies are sparse.

The emergence of the European Monetary Union (EMU) has brought this issue into focus. The European Council takes the view that 'sound' government finances are vital for 'price stability' and 'strong sustainable growth' 1 . In order to bolster fiscal discipline across member states and contain the levels of deficit within sustainable bounds, the European Council has adopted stringent fiscal rules. These rules, contained in the Stability and Growth Pact, set the maximum limits of deficit (3\% of GDP) and debt (60\% of GDP) and are mandatory to all member states ${ }^{2}$. The European Council reserves the right to impose fines should a member state exceed the deficit limit; the severity of fines is positively linked to the degree of violation of the limit. The rationale and the potency of these fiscal rules have been extensively debated elsewhere and we do not intend to do that here . Instead, our aim is to re-examine the fiscal sustainability of four Euro-zone countries (viz., Greece, Ireland, Italy and the Netherlands) whose government finances were dubbed unsustainable in 1991, the year of the signing of the Maastricht Treaty.

Corsetti and Roubini (1991), analyzing annual data spanning 1970-1989, reported that the government finances of these four countries were unsustainable. ${ }^{4} \mathrm{~A}$ decade has since elapsed; the Euro has become a reality. Whilst these countries had satisfied the

\footnotetext{
${ }^{1}$ See Resolution of the European Council on the Stability and Growth Pact, Amsterdam $17^{\text {th }}$ June 1997.

2 These rules are also well-known as Maastricht criteria for fiscal convergence.

${ }^{3}$ See, among others, Buiter, Corsetti and Roubini (1993), von Hagen and Eichengreen (1996) and Eichengreen and Wyplosz (1998).

${ }^{4}$ Corsetti and Roubini (1991) also found Belgium, amongst others, to be on an unsustainable fiscal path. Unfortunately, we had to drop Belgium from our analysis due to the lack of consistent data.
} 
3\% deficit criteria by 1997/1998 (see Arestis, Khan and Luintel, 2002), dissenting voices abound. It is alleged that many euro-zone countries achieved the budget deficit criteria through various 'fudges' and 'creative' accounting 5 . Moreover, the issue of sustainability remains. The satisfaction of the $3 \%$ deficit criterion is not equivalent to the satisfaction of the IBC. A continuum of budget deficit of the order of $3 \%$ of GDP would always satisfy the Maastricht criteria but that would not necessarily satisfy the present value criteria, for the discounted debt term would not converge to zero in the limit (see section II). Countries with positive levels of debt at time $t$ must run future surpluses in order to satisfy the IBC. Hence, the findings of Corsetti and Roubini, made more than a decade ago, act as important benchmarks in inquiring if the government finances of these euro-zone countries have now become sustainable. In a nutshell, the political establishment of EMU anticipates such a shift towards sustainability following the achievement of $3 \%$ deficit criteria. Our first motivation is to formally investigate whether this has indeed been the case.

The second motivation relates to the analysis of Corsetti and Roubini (1991) itself. They acknowledge that the validity of their results depends on the absence of structural breaks in the processes (i.e., the relevant measures of debt used). However, they were unable to address this issue because the econometric methods, at the time, were not developed to handle the tests of structural breaks involving nonstationary data (Corsetti and Roubini, 1991; p. 362). In fact, all influential work in this field Hamilton and Flavin (1986), Wilcox (1989), Hakkio and Rush (1991), Ahmed and Rogers (1995), Quintos (1995) and Bohn (1998) - emphasize that structural breaks must be accounted for while testing the IBC. For example, Ahmed and Rogers (1995) motivate their paper precisely on the issue of structural shifts arguing that structural stability is vital for agents to continue to believe in the solvency of government finances.

We explicitly model structural shifts while testing the present value criteria, an issue which has not been addressed before for this set of euro zone countries. ${ }^{6}$ Ahmed and

\footnotetext{
${ }^{5}$ Some examples of such 'devices' and 'creative' accounting pointed out are: the sale of Belgium Gold Reserves, French one-off transfer of 'France Telecom' pension fund to public sector, Italy's euro-tax etc. For details see Dafflon and Rossi (1998) and Arestis et al. (2001).

${ }^{6}$ Makrydakis et al. (1999) examine the sustainability of Greek fiscal policy by allowing one-time (endogenously determined) structural break. They find one structural shift in the Greek discounted debt
} 
Rogers determine break dates exogenously; we improve on their methodology by determining multiple breaks endogenously. It is now recognized that break dates must be identified endogenously (see Christiano, 1992; Perron, 1997). Moreover, in the light of recent literature (see Quintos, 1995), the tests implemented by Corsetti and Roubini (1991) are strong form tests of fiscal sustainability, which are not strictly required for the present value criterion to hold. We elaborate on these issues and perform both strong- and weak-form tests of sustainability. Thus, the main contributions of this paper are two-fold. First, it provides new insights into the fiscal sustainability of these countries based on extended data and a new econometric approach. Second, it establishes whether the findings of Corsetti and Roubini (1991) are sensitive to regime (structural) shifts and /or the forms of the tests (strong versus weak) employed.

Our results are distinct and interesting. First, we find evidence of multiple structural breaks in the path of public finances. Of the four countries analyzed, three show as many as four structural shifts. This casts doubt on studies that do not address structural breaks (e.g. Corsetti and Roubini, 1991) and / or allow for only one break (e.g., Makrydakis et al., 1999). Second, in sharp contrast to Corsetti and Roubini (1991), we find all sample countries to be on a sustainable fiscal path. This holds even before 1990 and even without considering the structural shifts. Corsetti and Roubini (1991) implemented strong form tests of sustainability, which entail more stringent conditions than those required for the IBC to hold. Most of our results satisfy weak form sustainability which is consistent with the IBC. We are able to reconcile our results with those of Corsetti and Roubini (see section VII). Finally, we find a clear Maastricht effect which is conducive to fiscal sustainability.

The rest of the paper is organized as follows: section II presents the analytical framework; section III reviews the relevant literature; section IV describes data; section $\mathrm{V}$ discusses econometric method; section VI presents empirical results; and section VII summarizes and concludes.

and conclude that government IBC is not satisfied. We improve on their methodology by allowing for and identifying multiple structural breaks. 


\section{Analytical Framework}

We express the dynamic budget constraint following Trehan and Walsh (1991). The one-period government budget constraint is given by:

$b_{t+1}=(1+r) b_{t}+g_{t}-\tau_{t}-s_{t}$

where $r$ is the real interest rate, $g_{t}$ is real government expenditure net of interest, $\tau_{t}$ is real tax revenues, $s_{t}$ is real revenue from seignorage (defined as changes in the real stock of base money). Note that the net-of-interest deficit is $d_{t}=g_{t}-\tau_{t}-s_{t}$. Since (1) holds for every period, taking expectation of (1) and solving for $b_{t}$ by recursive forward substitution yields:

$b_{t}=-\mathrm{E}_{t} \sum_{j=0}(1+r)^{-(J+1)}\left(g_{t+j}-\tau_{t+j}-s_{t+j}\right)+\operatorname{limE}_{j \rightarrow \infty}(1+r)^{-(J+1)} b_{t+j+1}$

where, $\mathrm{E}_{t}$ denotes the mathematical expectation operator conditional on information set at time t. Equation (2) is the standard intertemporal government budget constraint in expected value terms. It states that the outstanding stock of debt, $b_{t}$, equals the sum of the present values of (i) the flow primary surpluses and (ii) the stock of debt in the limit. The IBC requires that the limit term (bubble-term) in (2) be equal to zero (i.e., $\left.\lim _{j \rightarrow \infty} \mathrm{E}_{t}(1+r)^{-(J+1)} b_{t+j+1}=0\right)$ asymptotically. Thus, the government cannot leave a debt that has a positive expected present value in the limit; that would imply resorting to ponzi schemes i.e., bubble financing of government expenditures. The governments need to run future surpluses equal, in expected present value terms, to its current outstanding debt. A negative expected present value of debt in the limit implies supersolvency, i.e., asymptotically government is the net creditor to some other sector. However, the latter can be precluded on the grounds that no other country or sector is allowed to run ponzi schemes against the government (Ahmed and Rogers, 1995, p. 356). 


\section{Related Literature}

Empirical tests of IBC can be crudely grouped in terms of (i) their treatment of the real interest rate (r), and (ii) the test approaches they follow. Some treat real interest rate as constant whereas others treat it as stochastic. Unit root and /or co-integration appear to be the main forms of tests followed, although some studies directly test for the sign and the significance of the bubble term in (2). Hamilton and Flavin (1986) assume constant real interest rate and argue that the stationarity of primary surplus and/or the market value of debt, in real terms, is sufficient to deduce that the bubble term in (2) is asymptotically zero. They found US primary surplus and debt to be stationary and conclude that US government satisfied the IBC. However, Kremers (1988) and Wilcox (1989) show that Hamilton and Flavin's unit root tests suffer from the problem of serial correlation in residuals; once serial correlation is accounted for the findings of stationarity are reversed and US primary surplus and debt become nonstationary. Similarly, Haug (1991), using finite sample critical values, also refutes Hamilton and Flavin's findings ${ }^{\text {Q }}$.

Trehan and Walsh (1988) also assume constant real interest rate and show that the stationarity of deficit inclusive of interest payments and seignorage is necessary and sufficient for IBC to hold. This condition can be re-parameterized as a cointegrating vector of the form $(1-1-1)$ between $g$ (interest-cum-government expenditure), $\tau$ (tax receipts), and s (seignorage). According to Trehan and Walsh (1988), the stationarity of net of interest surplus, the measure used by Hamilton and Flavin (1986), is neither a necessary nor sufficient indicator of IBC under the assumption of constant real rate. Using US data spanning 1890-1986, Trehan and Walsh find deficit inclusive of interest to be stationary which supports sustainability. Unit root and co-integration tests indicate conflicting results, which they attribute to the non-constancy of real interest rate. Wilcox (1989) extends the Hamilton and Flavin's (1986) analysis by allowing stochastic violations of borrowing constraints and stochastic real interest rates. He finds US discounted debt to be non-stationary and concludes that US debt is unsustainable; he also reports evidence of parameter instability. 
Hakkio and Rush (1991), Trehan and Walsh (1991), Haug (1991), Ahmed and Rogers (1995) and Quintos (1995), on the other hand, employ co-integration tests. A typical cointegrating regression is:

$\mathrm{R}_{\mathrm{t}}=\alpha+\beta \mathrm{G}_{\mathrm{t}}+\mathrm{e}_{\mathrm{t}}$

where $R_{t}$ is government revenue (inclusive of seignorage) and $G_{t}$ is total government spending on goods and services, transfer payments, and interest on debt, both measured in real terms. Hakkio and Rush (1991) assume stochastic real interest rate and show that if $R_{t}$ and $G_{t}$ are both unit root processes, $I(1)$, then a co-integrating relation between the two is a necessary condition for the government budget constraints to hold. However, the co-integrating vector between $R_{t}$ and $G_{t}$ must be homogenous of degree one [1-1] in order to rule out infinite per capita debt in the limit. Using data from 1950(2) to 1988(4) they find co-integration between real revenue and expenditure with $\beta<1$. However, the evidence of a cointegrating relationship disappears in sub-sample analyses which prompt them to conclude that, in recent years, US fiscal deficit has become unsustainable.

Trehan and Walsh (1991) extend their (1988) work by relaxing the constancy of real interest rate and show that the stationarity of inclusive-of-interest deficit is a sufficient condition for IBC to hold. This is equivalent to the relationship (3) with a cointegrating vector $[1,0,-1]$. They show that as long as real interest rate is nonconstant, the solvency tests do not depend on the individual time series properties of government revenue and expenditure (i.e., $R_{t}$ and $G_{t}$ may be integrated of different orders ${ }^{8}$. Further, if the net-of-interest deficit and debt are both $\mathrm{I}(1)$, then the stationarity of inclusive-of-interest deficit implies solvency irrespective of whether real interest rate is constant or not. Using data from 1890 to 1996 they conclude: (i) US deficit conforms to IBC, and (ii) the real interest rate is variable. Ahmed and Rogers (1995) emphasize the stability of the co-integrating relationship between $G_{t}$ and $\mathrm{R}_{\mathrm{t}}$. Using time series data from the UK and the US, which stretched as far back as

\footnotetext{
${ }^{7}$ Hamilton and Flavin (1986) also directly test for the significance of bubble term and report results conducive to the sustainability of US public finances.

${ }^{8}$ However, the order of integration is important as long as real interest rates are assumed constant; in this case both must be I(1).
} 
two to three centuries, they find the cointegrating vector to be structurally stable. It is important to note, however, that they chose the break dates exogenously.

Quintos (1995) derives strong and weak conditions of sustainability tests. Her approach is fairly general in that it nests Hamilton and Flavin (1986), Hakkio and Rush (1991), Trehan and Walsh (1991) and Ahmed and Rogers (1995). In view of its generality we follow the approach taken by Quintos (1995). Sustainability conditions are as follows: (i) if $0<\beta<1$ in equation (3) then the IBC is satisfied in the weak sense irrespective of whether $R_{t}$ and $G_{t}$ are cointegrated or not; (ii) if $\beta=1$ and $R_{t}$ and $G_{t}$ are non-cointegrated then that also implies weak form sustainability; (iii) a cointegrated $R_{t}$ and $G_{t}$ with $\beta=1$ implies strong form sustainability; and (iv) $\beta=0$ implies unsustainable fiscal policy. The strong form sustainability corresponds to Hamiltan and Flavin's (1986) and Corsetti and Roubini's (1991) requirement; for $\Delta b$ is stationary if and only if $\beta=1$ and $R_{t}$ and $G_{t}$ are cointegrated. When deficits are weakly sustainable, the bubble term converges to zero at a slower rate than when they are strong form sustainable. Further, under weak form sustainability, the bubble term converges to zero more rapidly when $R_{t}$ and $G_{t}$ are cointegrated than when they are not. Although weak form sustainability is sufficient for the bubble term to go to zero in the limit, the deficit process and undiscounted debt may be mildly explosive. The latter may have serious policy implication as the government may have difficulty in marketing its debt. Hakkio and Rush make this point in terms of infinite per capita debt. Quintos examines the IBC for the US using a dataset spanning 1947(2) 1992(3). She endogenously identifies structural shift in US fiscal path in the early 1980s and shows that the US government finances were weak form sustainable despite non-integration between $R_{t}$ and $G_{t}$ beyond 1980 .

\section{Data}

We use time series on public expenditure $(G)$ and public revenue $(R)$ extracted from the IMF's International Financial Statistics (IFS). Public revenue is defined to include seignorage, which is proxied by the change in monetary base $\left(\mathrm{M}_{0}\right)$ in real terms. The data frequency is quarterly and covers a period of 1970(1)-1998(3) for Greece, 
1962(2)-1997(4) for Italy, and 1957(1)-1998(4) for Ireland and the Netherlands. ${ }^{0}$ The Consumer Price Index (CPI) is used to deflate the nominal series. Ideally, we would have liked to use the GDP deflator, but a sufficiently long and consistent series on GDP deflator is lacking for this set of countries.

Figure 1 plots the data in real terms. $G_{t}$ and $R_{t}$ are both trending. They also show seasonality, for which we account in the estimation stage. Greece, Ireland and Italy show sustained periods of close proximity as well as periods of divergence between $G_{t}$ and $R_{t}$. Greece, in particular, shows growing divergence between $G_{t}$ and $R_{t}$ since 1980 which peaks up around mid-1990s. However, following the stringent Maastricht criteria, Greek government revenue and expenditure have converged in a significant way by 1997. Italy shows a prolonged period of divergence between $G_{t}$ and $R_{t}$ which started in the early 1970s; however $\mathrm{G}_{\mathrm{t}}$ and $\mathrm{R}_{\mathrm{t}}$ converge in the late 1990s. Ireland shows a high level of deficit during 1970s and 1980s, but it has reduced significantly in the 1990s. Finally, the Netherlands shows less oscillatory government revenue and expenditure patterns; however, a blip in 1995 is apparent.

\section{Methodology}

A number of asymptotically efficient co-integration methods exist in the literature. However, in view of the relatively shorter sample of Greece and Italy we employ Dynamic OLS or GLS (DOLS or DGLS) estimators of co-integrating vector (Stock and Watson, 1993; Saikkonen, 1991), which is shown to perform better in small samples compared with a range of other asymptotically efficient estimators 10 . DOLS is asymptotically equivalent to Johansen's (1988) maximum-likelihood based estimator of cointegrating vectors when variables in the system are $\mathrm{I}(1)$ and there is a single cointegrating vector. Indeed, $R_{t}$ and $G_{t}$ both appear first order integrated in our dataset (see section VI). Further, our system is bivariate, so the issue of multicointegration does not arise. Thus, our choice of estimator accurately corresponds to

\footnotetext{
${ }^{9}$ In the case of Italy quarterly data on public expenditure is not available for the period 1992(1)1994(4). Hence, we extrapolated quarterly figures from annual data by imposing sample average quarterly weights.

${ }^{10}$ In their Monte Carlo investigations Stock and Watson (1993) find DOLS (DGLS) estimators to be preferable to a range of other estimators especially when sample size is short.
} 
the dimension of the system and the univariate properties of the data. The DOLS regression is given by:

$$
R_{t}=\beta_{0}+\beta_{1} G_{t}+\sum_{k=-k}^{k} \gamma_{k} \Delta G_{t-k}+\varepsilon_{t}
$$

where $R_{t}$ and $G_{t}$ respectively are government revenue and expenditures as specified in equation (3). Under the DOLS, the cointegrating regression is augmented by the lead and lag differences of regressors in order to control for the endogenous feedback and the nuisance parameters $\frac{11}{1}$. If $\varepsilon_{\mathrm{t}}$ is serially correlated then the appropriate estimator is DGLS; it allows for an autoregressive error under the Feasible Generalised Least Squares. The $\beta_{\mathrm{s}}$ are the cointegrating parameters. The estimated co-integrating vector, $\widehat{V}$, is given by $\widehat{\mathrm{V}}_{\mathrm{t}}=\mathrm{R}_{\mathrm{t}}-\widehat{\beta}_{0}-\widehat{\beta}_{1} \mathrm{G}_{\mathrm{t}}$, and its stationarity can be checked through any standard unit root test. Tests of various restrictions on the cointegrating parameters are implemented through Wald tests, which are $\chi^{2}$ distributed. A further advantage of this estimator is that it can also handle unbalanced regression, i.e. there is no need for $G_{t}$ and $R_{t}$ to be of the same order of integration. A downside however is that there is no unique method to determine the order of lead and lag. In view of the data frequency (quarterly) we set a fourth order lead and lag.

Shifts in fiscal regime are assessed through the tests of structural breaks in the cointegrating relationship between $R_{t}$ and $G_{t}$ (Ahmed and Rogers, 1995; Quintos, 1995). Break dates are identified through the sequential Wald tests (Quintos, 1995). The auxiliary regression for the stability test is:

$$
R_{t}=\beta_{0}+\beta_{1} G_{t}+\sum_{k=-k}^{k} \gamma_{k} \Delta G_{t-k}+\delta(D G)_{t}+v_{t}
$$

where

$$
\begin{array}{rlll}
D_{t} & =1 & \text { if } & \mathrm{t} \in T_{1}=(1, \ldots, \mathrm{m}) \\
& =0 & \text { if } & \mathrm{t} \in T_{2}=(\mathrm{m}+1, \ldots, \mathrm{T})
\end{array}
$$

and $m$ denotes the time of the breakpoint. The null of structural stability $\left(\mathrm{H}_{0}: \delta=0\right)$ is tested by the Wald test which is $\chi 2(1)$ distributed. In implementing these tests we trim $15 \%$ of the initial and final parts of the sample following Andrews (1993). If any of

\footnotetext{
${ }^{11}$ Note that the order of difference required for each regressor in generating the lead and lag term depends on the order of integration of the corresponding regressor. For example, if a regressor is I(2)
} 
the sequentially computed empirical Wald statistic, over $\mathrm{T}-2 \mathrm{k}_{0}\left(\mathrm{k}_{0}=\right.$ trimming parameter) regressions, is larger than the conventional 5\% critical value of $\chi^{2}(1)$ then that signifies the rejection of the null of structural stability.

Our empirical approach is structured as follows. First, we estimate the separate cointegrating relationship (equation 4), without accounting for any structural break, over the: (i) pre-oil-price shock, extending up to 1972(4); (ii) pre-Maastricht, extending up to 1991(4); (iii) full sample, extending up to 1998(4); and test for both weak and strong form sustainability. These specifications are treated as benchmark models, which would indicate if fiscal policy in these countries were sustainable during these distinct sample periods, and help reconcile our results with the existing ones. Further, they also act as a reference to assess whether sustainability results are sensitive to structural breaks. We then test for the structural stability of the cointegrating relationship between $R_{t}$ and $G_{t}$ as specified in equation 5 and identify the break dates endogenously. The long-run effect (total multiplier) of each identified structural shift on fiscal sustainability is estimated through suitably defined slope dummies (see below).

\section{Empirical Results}

As the first empirical step, we examined the univariate time series properties of $G_{t}$ and $R_{t}$. Tests reveal both $G_{t}$ and $R_{t}$ are unit root processes $\frac{12}{12}$ This implies that the cointegrating regression specified in equation (4) is directly applicable to this data set. In the estimation stage, we include seasonal dummies in order to account for the apparent seasonality in the data. Table 1 presents cointegration results for benchmark models along with a range of diagnostics. Where DOLS residuals are serially correlated, we report DGLS estimates. Results show that $G_{t}$ and $R_{t}$ are cointegrated in

then the lead and lag terms must be differenced twice (i.e., $\Delta\left(\Delta \mathrm{x}_{\mathrm{t}}\right)$ ). For further details see Stock and Watson (1993).

${ }^{12}$ We employed ADF (Dickey and Fuller, 1979) and KPSS (Kwiatkowski et al., 1992) tests in order to discriminate between stationary versus non-stationary processes. Both tests reveal $G_{t}$ and $R_{t}$ as nonstationary (unit root) processes. Since these results are well established in the literature, we do not report in order to conserve space; however they are available on request. 
all three samples for Greece $\frac{13}{\text {, }}$ the slope parameter is significantly different from zero, but the null of unit elasticity is rejected during the pre-Maastricht and the full sample but not before the 1980. Thus, Greek government finances appear to be strong form sustainable prior to 1980 s and weak form sustainable in the other two samples. Diagnostics show that residuals are well behaved, i.e., they are normal, homoscedastic and serially uncorrelated.

Ireland also shows strong form sustainability during the pre-oil shock period and weak-form sustainability in the other two samples. The null of unit elasticity is not rejected in any of the sample period analysed but the hypothesis of cointegration is maintained only for the pre-1973 period. However, a number of diagnostics appear problematic which may be attributed to the unaccounted structural breaks. Italy too shows weak form sustainability in all three periods analysed. The slope parameters are statistically significant in all cases but reject the null of unit elasticity. Further, $G_{t}$ and $\mathrm{R}_{\mathrm{t}}$ appear non-cointegrated in all three samples at the conventional (5\%) significance level. Interestingly, residual serial correlation is apparent even under a fourth order DGLS, which may be attributed to structural breaks. Likewise, the Netherlands shows weak form sustainability. $G_{t}$ and $R_{t}$ appear cointegrated in the full sample and the preMaastricht period but the slope parameters are statistically different from unity. However, prior to the first-oil-shock, the slope parameter is statistically unity but $G_{t}$ and $\mathrm{R}_{\mathrm{t}}$ appear non-cointegrated.

To sum up, the general picture is that all four countries' government finances appear sustainable irrespective of whether one focuses on the pre-oil-price shock period, preMaastricht period, or the full sample. Thus, all four countries satisfy IBC even without considering the structural breaks. Our findings are in sharp contrast to those of Corsetti and Roubini (1991), who reported public finances of these countries as unsustainable. However, before we dwell further on this set of results we examine the issue of structural shifts.

\footnotetext{
${ }^{13}$ Greek data starts only in 1970(1) therefore the first sample for Greece extends up to 1980(1) rather than 1972(4) as for the other countries. The choice of this cut-off point is not arbitrary: in 1981 the Greek government embarked upon a significant fiscal expansion (see Christodoulakis, 1994).
} 
Figure 2 plots the sequentially computed Wald tests under the null of stable cointegrating parameters as outlined in equation (5). Sequential tests are carried out over a period of 1963-92 for Ireland and the Netherlands, 1968-1993 for Italy and 1974-1993 for Greece. This variation in the test period is due to the different sample size across countries. The plot for Greece shows three clear breaks, which are significant at 5\% or better. These breaks appear to have occurred around 1976, 1980 and 1990. Likewise, four significant episodes of structural breaks are evident for Italy; two appear in the early and the late of 1970s, one in 1982 followed by a sustained period of 1986-1990 when all sequential Wald tests are significant. Ireland also shows four shifts. They are evident in 1966, 1974, 1982 and 1986-88. The Netherlands shows four structural shifts as well. They appear in 1971, 1974, 1985, and 1988-91. Thus, sequential Wald tests show that the cointegrating relationships between $R_{t}$ and $G_{t}$ have been through multiple structural shifts in all four countries analysed.

Structural breaks cannot fall too close together. We define a period of three years as the neighbourhood of a break and represent it by a single shift. The exact break date (point) in a neighbourhood is identified as the one that produces the highest Chisquare statistic in the sequential tests. Following this criterion, the exact break dates identified for Greece are 1976(1), 1980(1) and 1990(3); for Ireland they are 1966(2), 1974(1), 1982(3) and 1987(4); for Italy they are 1970(1), 1978(4), 1982(3) and 1988(3); and for the Netherlands they are 1971(4), 1974(4), 1985(2) and 1991(2).

Interestingly, in the majority of cases, the timing of these break dates corresponds to important economic events in the countries concerned. For Greece, the break of 1976(1) may be related to the aftermath of the first oil shock and the restoration of Democracy in the country which was accompanied by a number of nationalisations of loss-making private companies (see Alogoskoufis, 1995). The break of 1980(1) corresponds to the well-documented fiscal expansion engineered by Greek authorities in the early 1980s (see Christodoulakis 1994, Alogoskoufis 1995). Finally, the break of 1990(3) coincides with the introduction of the Greek convergence programmes aimed at EMU participation (see Arghyrou, 2000).

For Ireland, we could not find an obvious specific event to link the break of 1966(2); however it may reflect the era of the spectacular Irish macroeconomic performance of 
mid-1960s, which is characterised by low levels of budget deficit (see O'Grada and O'Rourke, 1996). The break of 1974 reflects Ireland's expansionary fiscal response to the first oil shock whereas that of 1982(3) coincides with the policy U-turn taken in the 1983 budget, which dismissed previous expansionary measures as "populist quick fixes". On the other hand, the break of 1987(4) corresponds to further determined fiscal consolidation measures introduced by the Irish authorities that year (see Giavazzi and Pagano, 1991).

In Italy, the break of 1970(1) may reflect the effect of the Autunno Caldo (Hot Autumn) events of 1969 when the Italian authorities, succumbing to the pressure of the then powerful Italian labour union, took a number of expenditure-increasing measures (see Rossi and Toniolo, 1996). We could not find an obvious reason for the break of 1978(4), although it's timing falls in the aftermath of the first oil price shock and quite close to the second oil shock. The break of 1982(3) may be related to the fiscal-discipline-inducing "divorce" between the Italian Central Bank and the Italian government. This untied the Central Bank from its obligation to buy all Treasury bonds that Italian government could not sell in the auction market (see Bank of Italy 1982, p. 217). Finally, the break of 1987(4) corresponds to a number of fiscal stabilisation measures taken by the Italian authorities in the late 1980s, aimed at ensuring the viability of the Lira's participation in the narrow-band of the ERM and achieving the fiscal targets required for EMU participation.

For the Netherlands, we could not find an economic event that could be linked to the break of 1971(4); however in view of its positive total multiplier (see below) this break may reflect the Dutch "golden economic years" of 1950-1973 characterised by a low level of fiscal deficit. The break of 1974(4) clearly coincides with the first oil shock whereas that of 1985(2) may be linked to the stabilising effect of a number of fiscal measures introduced by the Dutch authorities in the mid-1980s (see Avan Ark, de Haan and de Jong, 1996). Finally, the break of 1991 coincides with the signing of the Maastricht Treaty and the introduction of the Dutch convergence programmes.

Whether the fiscal sustainability improved or deteriorated following these regime shifts is an important issue. It is possible that some regime shifts do not necessarily exert significant long-run effects. We examine this issue by estimating the long run 
effect (total multiplier) of each endogenously identified break on fiscal sustainability. We define a slope dummy $\left(\mathrm{D}_{\mathrm{t}}\right)$ for each identified break point such that: $D_{t}=0$ if $\mathrm{t} \in$ $T_{1}=(1, \ldots, \mathrm{m}-1)$ and $\mathrm{D}_{\mathrm{t}}=\mathrm{G}_{\mathrm{t}}$ if $\mathrm{t} \in T_{2}=(\mathrm{m}, \mathrm{m}+1, \ldots, \mathrm{T})$, where $\mathrm{m}$ denotes the identified break date. Thus, the slope dummy for each break point takes a value of zero until the break date (m-1) and all nonzero values thereafter. This structure of dummy variables picks up the long-run effect of each regime shift and, when jointly estimated, their significance can be interpreted as indicative of the distinct effect of each regime shift. Ceteris paribus, a positive coefficient of slope dummy implies a move towards strong form sustainability because the bubble term rapidly converges to zero when $\beta \cong 1$ then, when $\beta<1$.

Table 2 presents results augmented by these structural shift dummies. For Greece, the total multiplier associated with the 1976 shift turned out to be insignificant suggesting that changes in fiscal regime of the mid-1970s did not have a lasting effect. However, the total multiplier corresponding to the shift of 1980(1) is significantly negative which indicates deteriorating sustainability; this is consistent with the fiscal expansion followed by the Greek authorities in 1980s and her worsening government finances (see Christodoulakis, 1994; Alogoskoufis, 1995). The positive and significant total multiplier associated with the shift of 1990s is interesting. This suggests that the convergence programmes, following the Maastrich Treaty, implemented by the Greek authorities in the 1990s have achieved improvements on Greek government finances. The null of the overall slope of unity (i.e., $\mathrm{H}_{0}$ : $\beta_{1}+\phi_{1}+\phi_{2}=1$ ) is not rejected for the pre1980 period but they are rejected in the other two samples. For the pre-Maastricht and the full sample $0<\beta_{1}+\phi_{1}+\phi_{2}<1$. Further, $G_{t}$ and $R_{t}$ are cointegrated in all cases. Thus, government finances in Greece satisfy strong form sustainability prior to 1980 and weak form sustainability in the other two periods.

The estimated total multipliers for Ireland suggest that the structural break of the mid1960s had a significantly positive effect on government finances, which is consistent with a period of spectacular growth and low levels of deficit (O'Grada and O'Rourke, 1996). The break of 1974, ascribed to the first oil-price-shock, had a negative effect, which is again consistent with a priori expectation. The successive regime shifts of 1982 and 1987 appear to have improved the fiscal sustainability of Ireland. This is 
consistent with the Irish divorce with expansionary policy and its concerted efforts to achieve the Maastricht criterion of $3 \%$ deficit level. Irish $G_{t}$ and $R_{t}$ are cointegrated when structural shifts are accounted for. This result is important because the Irish $G_{t}$ and $R_{t}$ were non-cointegrated for the pre-Maastricht and the full samples when structural shifts were ignored. The overall slope coefficient (i.e., $\mathrm{H}_{0}: \beta_{1}+\phi_{1}+\phi_{2}+\phi_{3}+$ $\left.\phi_{4}=1\right)$ is statistically not different from unity for the pre-oil-shock and the full samples. The null of unity is rejected for the pre-Maastrich period only. Thus, Irish government finances appear strong form sustainable during the pre-oil-shock and the full sample but only weak form sustainable for the pre-Maastrich period.

For Italy, the shift of early 1970 appears to have deteriorated her fiscal sustainability which is consistent with the effects of Autunno Caldo discussed above. Interestingly, the structural shifts of 1978(4) and 1982(3) appear insignificant suggesting that they had no lasting effect on the fiscal status of Italy. However, the shift identified nearer to the Maastricht treaty shows a significantly positive effect on fiscal sustainability. Italian $R_{t}$ and $G_{t}$ are cointegrated in all but the pre-oil-crisis period. This result is also interesting in that the benchmark model shows non-cointegration between $R_{t}$ and $G_{t}$ for Italy in all samples. The overall slope coefficient is always statistically significantly different from zero but less than unity (i.e., $0<\beta_{1}+\phi_{1}+\phi_{2}<1$ ). Thus, Italian government finances always satisfied the weak form sustainability and hence the IBC.

Finally, for the Netherlands the structural shift of 1971 shows a positive and significant effect on her fiscal sustainability which is consistent with the so called "golden years" effect discussed above. However, the break of 1974 had an adverse effect which is consistent with the fiscal pressure of the first oil-price-shock. The structural shift of 1985 appears insignificant, but that of 1991, i.e. the one ascribed to the Maastrict Treaty, appears to have improved the fiscal sustainability. Dutch $\mathrm{R}_{\mathrm{t}}$ and $\mathrm{G}_{\mathrm{t}}$ are cointegrated in all samples although the benchmark model had shown noncointegration during the pre-oil-shock period. The overall slope coefficient is less than unity (i.e., $0<\beta_{1}+\phi_{1}+\phi_{2}<1$ ). Thus, in the Netherlands, $R_{t}$ and $G_{t}$ are cointegrated and the government finances satisfy weak form sustainability during all three periods analysed. 
Overall, the majority of endogenously identified structural shifts correspond to important policy changes in respective economies and most of them produce anticipated effects on fiscal sustainability. Moreover, the incorporation of structural breaks in the analysis increases the instances of cointegration between $R_{t}$ and $G_{t}$, which is clear evidence in favour of a strengthened fiscal sustainability. However, there are few regime shifts, which had no statistically significant effect on sustainability.

\section{Summary and conclusions}

Corsetti and Roubini (1991) showed, amongst other things, that the government finances of Greece, Ireland, Italy and the Netherlands were unsustainable. All four are now euro-zone countries and the issue of fiscal sustainability is of paramount importance. Since 1991 there have been important changes in these economies. They did satisfy the $3 \%$ deficit criteria by the launch of the Euro. Nevertheless sceptics allege that many euro-zone countries used various 'fudges' and 'creative' accounting in achieving the $3 \%$ deficit criteria. Besides, the issue of fiscal sustainability is a different one. As shown above, the satisfaction of the $3 \%$ deficit criterion is not equivalent to the satisfaction of the intertemporal budget constraint, for countries in deficit at time $\mathrm{t}$ must run surpluses in future such that the bubble term (the discounted debt term) converges to zero in the limit.

In this paper we re-examine the issue of fiscal sustainability in these four countries. We take forward the analysis by way of new empirical techniques and extended dataset. The IBC is examined across different samples: (i) the pre-oil-price shock period, extending up to 1972(4); (ii) the pre-Maastricht period, extending up to 1991(4); and (iii) the full sample, extending up to 1998(4). This allows us to evaluate if government finances were sustainable across various distinct periods in the sample. Corsetti and Roubini (1991) cautioned that their results might be sensitive to structural shifts, which they were unable to address. We address the issue of multiple structural shifts while testing the fiscal sustainability. Regime shifts are identified endogenously. 
Our results are interesting. First, in sharp contrast to Corsetti and Roubini (1991), we find that government finances in all four countries satisfied the present value criteria across all sample periods even without considering the structural shifts. Second, over the last 40 years or so all sample countries have been through multiple structural shifts. Of the four countries analyzed, three showed as many as four structural shifts in their fiscal regime. We are able to link the majority of these shifts to important policy changes in respective countries. We also find that, in most cases, these regime shifts produced an effect on fiscal sustainability that was pretty much anticipated. Third, for all sample countries, we find one of the structural breaks either in the late 1980s or the early 1990s, which we ascribe to the Maastrich Treaty. The effect of this structural shift has been significantly positive for all countries. We interpret this as the positive effect of the Maastricht's deficit convergence criteria on the fiscal sustainability of these countries. Overall, our results corroborate the anticipation of the European Council that the deficit criteria will have a positive effect on the fiscal solvency of these economies. Fourth, we find that allowing for structural shifts increases the instances of cointegration between $R_{t}$ and $G_{t}$. This is a clear indication in favor of improved fiscal sustainability. Thus, failure of cointegration between $R_{t}$ and $\mathrm{G}_{\mathrm{t}}$, reported by some earlier literature, may be attributed to their inability to account for structural shifts in fiscal regime.

A few words to reconcile our results with those of Corsetti and Roubini are in order. They implemented a strong form test of sustainability which requires: (i) $G_{t}$ and $R_{t}$ be cointegrated; and (ii) cointegrating vector between them be homogenous of degree one [1, -1]. However, as shown by Quintos (1995), in its strict sense, IBC holds if weak form sustainability is satified. We reject strong form sustainability in most cases, which is consistent with the findings of Corsetti and Roubini. Our results mainly show weak form sustainability, a sufficient condition in itself to establish that the government finances of sample countries are consistent with IBC. Since fiscal deficit levels are capped below 3\% of GDP and the euro zone is characterized by a low real rate of interest, the fear that the rejection of strong form sustainability may lead to infinite per-capita debt in the long-run appears more conjecture than real. 
Table 1 - Analysis without breaks

\section{APPENDIX}

\begin{tabular}{|c|c|c|c|}
\hline \multicolumn{4}{|l|}{ GREECE } \\
\hline 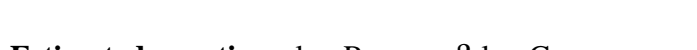 & DGLS full sample & DOLS pre-Maastricht & DOLS pre-1980s \\
\hline Estimated equation: $\log R_{t}=\alpha+\beta \log G_{t}+u_{t}$ & 1970(1)-1998(3) & 1970(1)-1991(4) & 1970(1)-1980(1) \\
\hline$\alpha \quad\left(p\right.$-value of Wald test $\left.-H_{0}: \alpha=0\right)$ & $0.896(0.00)$ & $1.110(0.00)$ & $0.507(0.12)$ \\
\hline $\log G\left(p\right.$-value of Wald test $\left.-H_{0}: \beta=0\right)$ & $0.708(0.00)$ & $0.633(0.00)$ & $0.859(0.00)$ \\
\hline p-value of Wald test, $\mathrm{H}_{0}: \beta=1$ & $0.00 * *$ & $0.00 * *$ & 0.60 \\
\hline t-ADF on $\hat{u}_{t}$ (Lag Order $)-[5 \%$ critical value $]$ & $-3.50(3)^{* *}[-2.888]$ & $-2.905(7) *[-2.898]$ & $-7.817 * *(4)[-2.938]$ \\
\hline \multicolumn{4}{|l|}{ Mispecification tests (p-values) } \\
\hline L M F-test for $4^{\text {th }}$ order autocorrelation & $0.82(2)$ & 0.38 & 0.17 \\
\hline $\mathrm{Chi}^{2} \mathrm{BJ}$ test for non-normality & 0.69 & 0.77 & 0.95 \\
\hline LM F-test for ARCH & 0.95 & 0.73 & 0.76 \\
\hline White's Chi ${ }^{2}$ test for heteroscedasticity & 0.97 & 0.56 & N/A \\
\hline Inference & Weak form sustainability & Weak form sustainability & Strong form sustainability \\
\hline \multicolumn{4}{|l|}{ IRELAND } \\
\hline Estimated equation: $\log R_{t}=\alpha+\beta \log G_{t}+u_{t}$ & $\begin{array}{l}\text { DGLS full sample } \\
\text { 1957(1)-1998(4) }\end{array}$ & $\begin{array}{l}\text { DGLS pre-Maastricht } \\
\text { 1957(1)-1991(4) }\end{array}$ & $\begin{array}{l}\text { DGLS pre-oil crisis } \\
\text { 1957(1)-1972(4) }\end{array}$ \\
\hline$\alpha \quad\left(p\right.$-value of Wald test $\left.-H_{0}: \alpha=0\right)$ & $-0.394(0.40)$ & $-0.210(0.61)$ & $-0.626(0.07)$ \\
\hline $\log \mathrm{G}\left(\mathrm{p}\right.$-value of Wald test $\left.-\mathrm{H}_{0}: \beta=0\right)$ & $1.107(0.00)$ & $1.049(0.00)$ & $1.162(0.00)$ \\
\hline $\mathrm{p}$-value of Wald test, $\mathrm{H}_{0}: \beta=1$ & 0.45 & 0.70 & 0.14 \\
\hline t-ADF on $\hat{u}_{t}($ Lag Order $)-[5 \%$ critical value $]$ & $-2.291(5)[-2.881]$ & $-2.088(3)[-2.884]$ & $-10.412 * *[-2.917]$ \\
\hline \multicolumn{4}{|l|}{ Mispecification tests (p-values) } \\
\hline L M F-test for $4^{\text {th }}$ order autocorrelation & 0.10 & 0.29 & 0.74 \\
\hline $\mathrm{Chi}^{2} \mathrm{BJ}$ test for non-normality & $0.00 * *$ & $0.00 * *$ & 0.09 \\
\hline LM F-test for ARCH & $0.00 * *$ & $0.03 *$ & 0.50 \\
\hline White's Chi ${ }^{2}$ test for heteroscedasticity & $0.00^{* *}$ & $0.00^{* *}$ & $0.00 * *$ \\
\hline Inference & Weak form sustainability & Weak form sustainability & Strong form sustainability \\
\hline
\end{tabular}

Note: *,* denote significance at the $5 \%$ and $1 \%$ level respectively. 
Table 1 - Analysis without breaks (continued)

\begin{tabular}{|c|c|c|c|}
\hline \multicolumn{4}{|l|}{ ITALY } \\
\hline Estimated equation: $\log R_{t}=\alpha+\beta \log G_{t}+u_{t}$ & $\begin{array}{l}\text { DGLS full sample } \\
\text { 1962(2)-1998(4) }\end{array}$ & $\begin{array}{l}\text { DGLS pre-Maastricht } \\
\text { 1962(2)-1991(4) }\end{array}$ & $\begin{array}{l}\text { DGLS pre-oil crisis } \\
1962(2)-1972(4)\end{array}$ \\
\hline$\alpha \quad\left(p\right.$-value of Wald test $\left.-\mathrm{H}_{0}: \alpha=0\right)$ & $0.150(0.04)$ & $0.243(0.00)$ & $0.463(0.00)$ \\
\hline $\log \mathrm{G}\left(\mathrm{p}\right.$-value of Wald test $\left.-\mathrm{H}_{0}: \beta=0\right)$ & $0.915(0.00)$ & $0.853(0.00)$ & $0.706(0.00)$ \\
\hline$p$-value of Wald test, $H_{0}: \beta=1$ & $0.03 *$ & $0.00 * *$ & $0.00 * *$ \\
\hline t-ADF on $\hat{u}_{t}($ Lag Order $)-[5 \%$ critical value $]$ & $-1.254(6)[-2.883]$ & $-2.784(6)[-2.887]$ & $-2.276(3)[-2.938]$ \\
\hline \multicolumn{4}{|l|}{ Mispecification tests (p-values) } \\
\hline L M F-test for $4^{\text {th }}$ order autocorrelation & $0.00 * *$ & $0.00 * *$ & 0.91 \\
\hline $\mathrm{Chi}^{2} \mathrm{BJ}$ test for non-normality & 0.84 & 0.81 & 0.26 \\
\hline LM F-test for ARCH & 0.14 & 0.84 & 0.44 \\
\hline White's $\mathrm{Chi}^{2}$ test for heteroscedasticity & 0.29 & 0.39 & 0.67 \\
\hline Inference & Weak form sustainability & Weak form sustainability & Weak form sustainability \\
\hline \multicolumn{4}{|l|}{ THE NETHERLANDS } \\
\hline Estimated equation: $\log R_{t}=\alpha+\beta \log G_{t}+u_{t}$ & $\begin{array}{l}\text { DGLS full sample } \\
\text { 1957(1)-1998(4) }\end{array}$ & $\begin{array}{l}\text { DGLS pre-Maastricht } \\
\text { 1957(1)-1991(4) }\end{array}$ & $\begin{array}{l}\text { DGLS pre-oil crisis } \\
\text { 1957(1)-1972(4) }\end{array}$ \\
\hline$\alpha \quad\left(p\right.$-value of Wald test $\left.-\mathrm{H}_{0}: \alpha=0\right)$ & $0.793(0.00)$ & $0.762(0.00)$ & $0.389(0.00)$ \\
\hline $\log \mathrm{G}\left(\mathrm{p}\right.$-value of Wald test $\left.-\mathrm{H}_{0}: \beta=0\right)$ & $0.832(0.00)$ & $0.839(0.00)$ & $0.928(0.00)$ \\
\hline$p$-value of Wald test, $H_{0}: \beta=1$ & $0.00 * *$ & $0.00 * *$ & 0.50 \\
\hline $\mathrm{t}-\mathrm{ADF}$ on $\hat{u}_{t}($ Lag Order $)-[5 \%$ critical value $]$ & $-3.814 * *(5)[-2.880]$ & $-3.473 * *(5)[-2.883]$ & $-2.814(5)[-2.915]$ \\
\hline \multicolumn{4}{|l|}{ Mispecification tests (p-values) } \\
\hline L M F-test for $4^{\text {th }}$ order autocorrelation & 0.43 & 0.45 & 0.35 \\
\hline $\mathrm{Chi}^{2} \mathrm{BJ}$ test for non-normality & 0.79 & 0.23 & 0.92 \\
\hline LM F-test for ARCH & 0.30 & 0.32 & 0.84 \\
\hline White's Chi ${ }^{2}$ test for heteroscedasticity & 0.52 & 0.64 & 0.40 \\
\hline Inference & Weak form sustainability & Weak form sustainability & Weak form sustainability \\
\hline
\end{tabular}

Note: $* * *$ denote significance at the $5 \%$ and $1 \%$ level respectively. 
Table 2 - Analysis with breaks

\begin{tabular}{|c|c|c|c|}
\hline \multicolumn{4}{|l|}{ GREECE } \\
\hline D. & DOLS full sample: & DOLS pre-Maastricht & DOLS pre-1980s \\
\hline Estimated equation: $\log R_{t}=\alpha+\beta \log G_{t}+\phi_{1} D 1 \log G_{t}+\phi_{2} D 2 \log G_{t}+u_{t}$ & 1970(1)-1998(3) & 1970(1)-1991(4) & 1970(1)-1980(1) \\
\hline$\alpha \quad\left(p\right.$-value of Wald test $\left.-H_{0}: \alpha=0\right)$ & $0.769(0.02)$ & $0.715(0.00)$ & $0.507(0.12)$ \\
\hline $\log \mathrm{G}\left(\mathrm{p}\right.$-value of Wald test $-\mathrm{H}_{0}: \beta=0$ ) & $0.755(0.00)$ & $0.764(0.00)$ & $0.859(0.00)$ \\
\hline D1 $\log G$ (p-value of Wald test $-H_{0}: \phi_{1}=0, D 1=1$ in $1980(1)-1998(3)$ & $-0.015(0.03)$ & $-0.015(0.00)$ & \\
\hline D2 $\log G$ (p-value of Wald test $-\mathrm{H}_{0}: \phi_{2}=0, \mathrm{D} 2=1$ in 1990(3)-1998(3) & $0.0123(0.05)$ & & \\
\hline p-value of Wald test, $\mathrm{H}_{0}: \beta+\phi_{1}+\phi_{2}=0$ & $0.00^{* *}$ & $0.00^{* *}$ & $0.00^{* *}$ \\
\hline p-value of Wald test, $H_{0}: \beta+\phi_{1}+\phi_{2}=1$ & $0.00 * *$ & $0.00 * *$ & 0.60 \\
\hline $\mathrm{t}-\mathrm{ADF}$ on $\hat{u}_{t}(\mathrm{p}$-value) (Lag Order $)-[5 \%$ critical value $]$ & $-4.520(3)^{* *}[-2.887]$ & $-3.054(7) *[-2.898]$ & $-7.817 * *(4)[-2.938]$ \\
\hline \multicolumn{4}{|l|}{ Mispecification tests (p-values) } \\
\hline LM F-test for $4^{\text {th }}$ order autocorrelation & 0.68 & 0.62 & 0.17 \\
\hline $\mathrm{Chi}^{2} \mathrm{BJ}$ test for non-normality & 0.30 & 0.82 & 0.95 \\
\hline LM F-test for ARCH & 0.91 & 0.96 & 0.76 \\
\hline White's $\mathrm{Chi}^{2}$ test for heteroscedasticity & 0.94 & 0.74 & N/A \\
\hline Inference & Weak form sustainability & Weak form sustainability & Strong form sustainability \\
\hline \multicolumn{4}{|l|}{ IRELAND } \\
\hline $\begin{array}{l}\text { Estimated equation: } \log R_{t}=\alpha+\beta \log G_{t}+\phi_{1} D 1 \log G_{t}+\phi_{2} D 2 \log G_{t}+\phi_{3} D 3 \log G_{t} \\
+\phi_{4} D 4 \log G_{t}+u_{t}\end{array}$ & $\begin{array}{l}\text { DGLS full sample: } \\
\text { 1957(1)-1998(4) }\end{array}$ & $\begin{array}{c}\text { DGLS pre-Maastricht } \\
\text { 1957(1)-1991(4) }\end{array}$ & $\begin{array}{c}\text { DGLS pre-Maastricht } \\
\text { 1957(1)-1972(4) }\end{array}$ \\
\hline$\alpha \quad\left(p\right.$-value of Wald test $\left.-H_{0}: \alpha=0\right)$ & $0.090(0.58)$ & $0.302(0.01)$ & $0.129(0.52)$ \\
\hline $\log G\left(p\right.$-value of Wald test $\left.-H_{0}: \beta=0\right)$ & $0.936(0.00)$ & $0.865(0.00)$ & $0.894(0.00)$ \\
\hline D1 $\log \mathrm{G}$ (p-value of Wald test $-\mathrm{H}_{0}: \phi_{1}=0, \mathrm{D} 1=1$ in $1966(2)-1997(4)$ & $0.018(0.00)$ & $0.023(0.00)$ & $0.020(0.00)$ \\
\hline $\mathrm{D} 2 \operatorname{logG}$ (p-value of Wald test $-\mathrm{H}_{0}: \phi_{2}=0, \mathrm{D} 2=1$ in 1974(1)-1997(4) & $-0.016(0.00)$ & $-0.010(0.00)$ & \\
\hline D3 $\log G\left(p\right.$-value of Wald test $-H_{0}: \phi_{3}=0, D 3=1$ in 1982(3)-1997(4) & $0.0074(0.05)$ & $0.008(0.00)$ & \\
\hline D4 $\log G$ (p-value of Wald test $-H_{0}: \phi_{4}=0, D 4=1$ in $1987(4)-1997(3)$ & $0.029(0.00)$ & $0.024(0.00)$ & \\
\hline p-value of Wald test, $\mathrm{H}_{0}: \beta+\phi_{1}+\phi_{2}+\phi_{3}+\phi_{4}=0$ & $0.00 * *$ & $0.00^{* *}$ & $0.00 * *$ \\
\hline p-value of Wald test, $H_{0}: \beta+\phi_{1}+\phi_{2}+\phi_{3}+\phi_{4}=1$ & 0.59 & $0.00 * *$ & 0.18 \\
\hline $\mathrm{t}-\mathrm{ADF}$ on $\hat{u}_{t}$ (p-value) (Lag Order ) - [5\% critical value] & $-5.266(4)^{* *}[-2.880]$ & $-5.551(3)^{* *}[-2.883]$ & $-3.670(3)^{* *}[-2.911]$ \\
\hline \multicolumn{4}{|l|}{ Mispecification tests (p-values) } \\
\hline LM F-test for $4^{\text {th }}$ order autocorrelation & 0.47 & 0.59 & 0.98 \\
\hline $\mathrm{Chi}^{2} \mathrm{BJ}$ test for non-normality & 0.19 & 0.21 & 0.26 \\
\hline LM F-test for ARCH & 0.29 & 0.08 & 0.92 \\
\hline White's $\mathrm{Chi}^{2}$ test for heteroscedasticity & 0.07 & $0.02 *$ & 0.89 \\
\hline Inference & Strong form sustainability & Weak form sustainability & Strong form sustainability \\
\hline
\end{tabular}


Table 2 (continued) - Analysis with breaks

\begin{tabular}{|c|c|c|c|}
\hline \multicolumn{4}{|l|}{ ITALY } \\
\hline Estimated equation: $\log R=\alpha+\beta \log G_{1}+\phi_{1} D 1 \log G_{1}+\phi_{2} D 2 \log G+1$ & $\begin{array}{l}\text { DOLS full sample: } \\
\text { 1962(2)-1998(4) }\end{array}$ & $\begin{array}{l}\text { DOLS pre-Maastrict } \\
1962(2)-1991(4)\end{array}$ & $\begin{array}{l}\text { DGLS pre-oil crisis } \\
\text { 1962(2)-1972(4) }\end{array}$ \\
\hline $\begin{array}{l}\text { EStmatea equation: } \log \mathrm{K}_{\mathrm{t}}=\alpha+p \log \mathrm{U}_{\mathrm{t}}+\phi_{1} D 1 \log \mathrm{U}_{\mathrm{t}}+\phi_{2} D 2 \log \mathrm{U}_{\mathrm{t}}+\mathrm{u}_{\mathrm{t}} \\
\left.\alpha \text {-value of Wald test }-\mathrm{H}_{0}: \alpha=0\right)\end{array}$ & $0.195(0.00)$ & $0.163(0.00)$ & $0.463(0.00)$ \\
\hline $\log G\left(p-\right.$-value of Wald test $\left.-H_{0}: \beta=0\right)$ & $0.912(0.00)$ & $0.932(0.00)$ & $0.706(0.00)$ \\
\hline D1 $\log$ (p-value of Wald test $-H_{0}: \phi_{1}=0, D 1=1$ in $1970(1)-1997(3)$ & $-0.038(0.00)$ & $-0.043(0.00)$ & \\
\hline D2 $\operatorname{logG}\left(\mathrm{p}\right.$-value of Wald test $-\mathrm{H}_{0}: \phi_{2}=0, \mathrm{D} 2=1$ in $1988(3)-1997(3)$ & $0.033(0.00)$ & $0.021(0.00)$ & \\
\hline p-value of Wald test, $\mathrm{H}_{0}: \beta+\phi_{1}+\phi_{2}=0$ & $0.00 * *$ & $0.00 * *$ & $0.00 * *$ \\
\hline p-value of Wald test, $H_{0}: \beta+\phi_{1}+\phi_{2}=1$ & $0.00^{* *}$ & $0.00^{* * *}$ & $0.00^{* *}$ \\
\hline $\mathrm{t}$-ADF on $\hat{u}_{t}(\mathrm{p}$-value $)($ Lag Order $)-[5 \%$ critical value $]$ & $-3.777(3) * *[-2.882]$ & $-5.103(6) * *[-2.887]$ & $-2.276(3)[-2.938]$ \\
\hline \multicolumn{4}{|l|}{ Mispecification tests (p-values) } \\
\hline LM F-test for $4^{\text {th }}$ order autocorrelation & 0.75 & 0.28 & 0.91 \\
\hline $\mathrm{Chi}^{2} \mathrm{BJ}$ test for non-normality & 0.36 & 0.74 & 0.26 \\
\hline LM F-test for ARCH & 0.93 & 0.27 & 0.44 \\
\hline White's $\mathrm{Chi}^{2}$ test for heteroscedasticity & 0.28 & 0.30 & 0.67 \\
\hline Inference & Weak form sustainability & Weak form sustainability & Weak form sustainability \\
\hline \multicolumn{4}{|l|}{ THE NETHERLANDS } \\
\hline Estimated equation: $\log R_{t}=\alpha+\beta \log G_{t}+\phi_{1} D 1 \log G_{t}+\phi_{2} D 2 \log G_{t}+\phi_{3} D 3 \log G_{t}+u_{t}$ & $\begin{array}{l}\text { DGLS full sample: } \\
\text { 1957(1)-1998(4) }\end{array}$ & $\begin{array}{l}\text { DGLS pre-Maastricth } \\
\text { 1957(1)-1991(4) }\end{array}$ & $\begin{array}{l}\text { DOLS pre-oil crisis } \\
1957(1)-1972(4)\end{array}$ \\
\hline$\alpha \quad\left(p\right.$-value of Wald test $\left.-H_{0}: \alpha=0\right)$ & $0.774(0.00)$ & $0.737(0.00)$ & $0.452(0.00)$ \\
\hline $\log G\left(p\right.$-value of Wald test $-H_{0}: \beta=0$ ) & $0.831(0.00)$ & $0.841(0.00)$ & $0.910(0.00)$ \\
\hline D1 $\operatorname{logG}$ (p-value of Wald test $-H_{0}: \phi_{1}=0, D 1=1$ in 1971(4)-1997(3) & $0.0096(0.00)$ & $0.0093(0.00)$ & $0.0090(0.00)$ \\
\hline $\mathrm{D} 2 \operatorname{logG}\left(\mathrm{p}\right.$-value of Wald test $-\mathrm{H}_{0}: \phi_{2}=0, \mathrm{D} 2=1$ in 1974(4)-1997(3) & $-0.0070(0.00)$ & $-0.0076(0.00)$ & - \\
\hline D2 $\log \mathrm{G}$ (p-value of Wald test $-\mathrm{H}_{0}: \phi_{3}=0, \mathrm{D} 3=1$ in 1991(2)-1997(4) & $0.0060(0.00)$ & $0.0081(0.00)$ & - \\
\hline p-value of Wald test, $\mathrm{H}_{0}: \beta+\phi_{1}+\phi_{2}+\phi_{3}=0$ & $0.00^{* *}$ & $0.00^{* *}$ & $0.00^{* *}$ \\
\hline p-value of Wald test, $H_{0}: \beta+\phi_{1}+\phi_{2}+\phi_{3}=1$ & $0.00 * *$ & $0.00 * *$ & $0.00 * *$ \\
\hline $\mathrm{t}$-ADF on $\hat{u}_{t}$ (p-value) (Lag Order $)-[5 \%$ critical value $]$ & $-4.894(5)^{* *}[-2.980]$ & $-4.515(5) * *[-2.883]$ & $-4.449(5) * *[-2.913]$ \\
\hline $\begin{array}{l}\text { Mispecification tests (p-values) } \\
\text { LM F-test for } 4^{\text {th }} \text { order autocorrelation } \\
\text { Chi }^{2} \text { BJ test for non-normality } \\
\text { LM F-test for ARCH } \\
\text { White's Chi' }{ }^{2} \text { test for heteroscedasticity } \\
\text { White's F-test for heteroscedasticity/functional form } \\
\text { RESET F-test for functional form }\end{array}$ & $\begin{array}{l}0.60 \\
0.37 \\
0.39 \\
0.15\end{array}$ & $\begin{array}{l}0.50 \\
0.07 \\
0.87 \\
0.72\end{array}$ & $\begin{array}{l}0.94 \\
0.20 \\
0.86 \\
0.67\end{array}$ \\
\hline Inference & Weak form sustainability & Weak form sustainability & Weak form sustainability \\
\hline
\end{tabular}

Notes: *,** denote significance at the 5\% and $1 \%$ level respectively. DGLS equations for Italy and the Netherlands have been estimated using fifth order leads and lags to avoid non-normality of residuals. When fourth order lead and lags are used, results remain qualitatively identical but normality fails. 
Figure 1: Real Government Revenue (R) and Expenditure (G) in logs
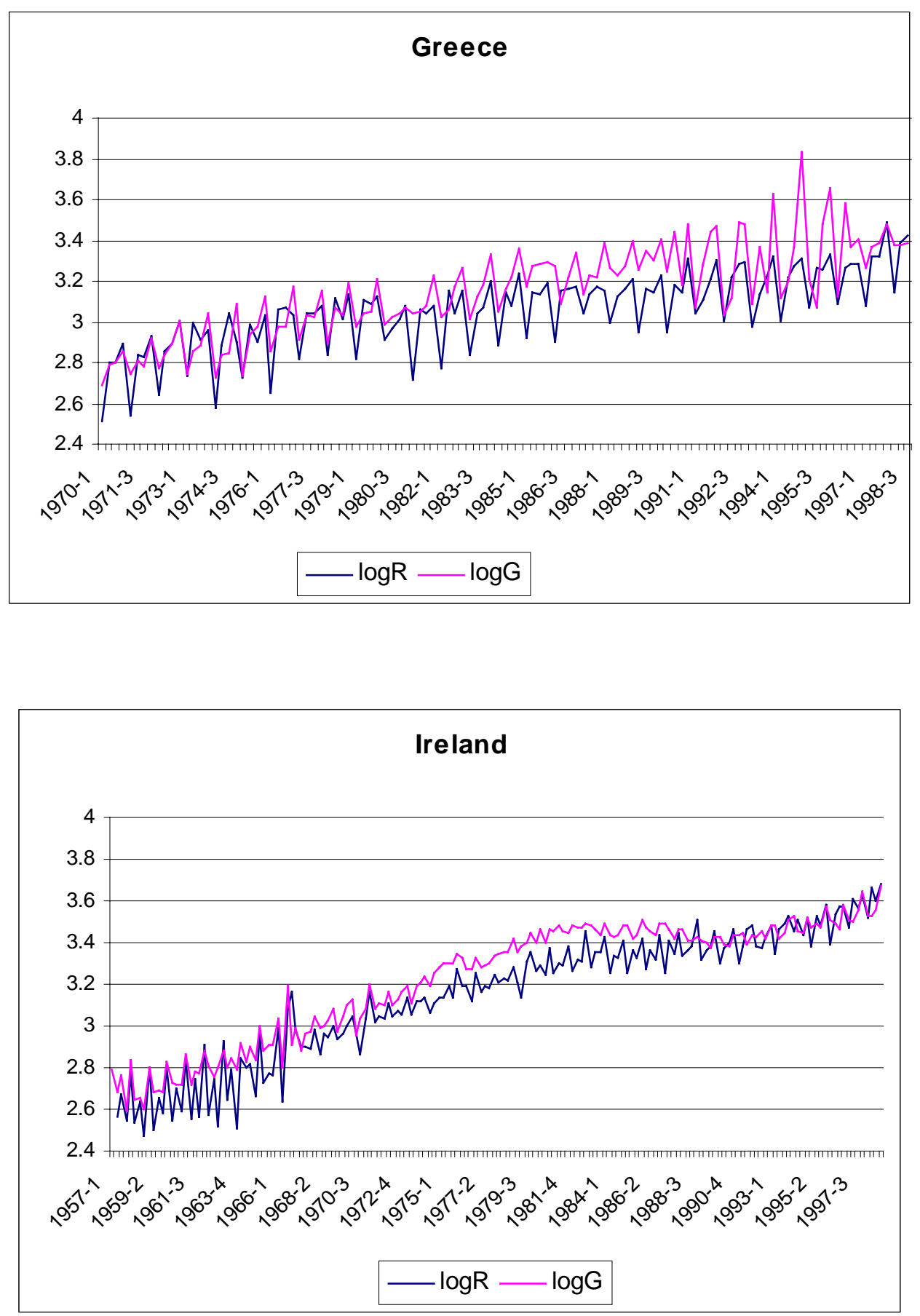

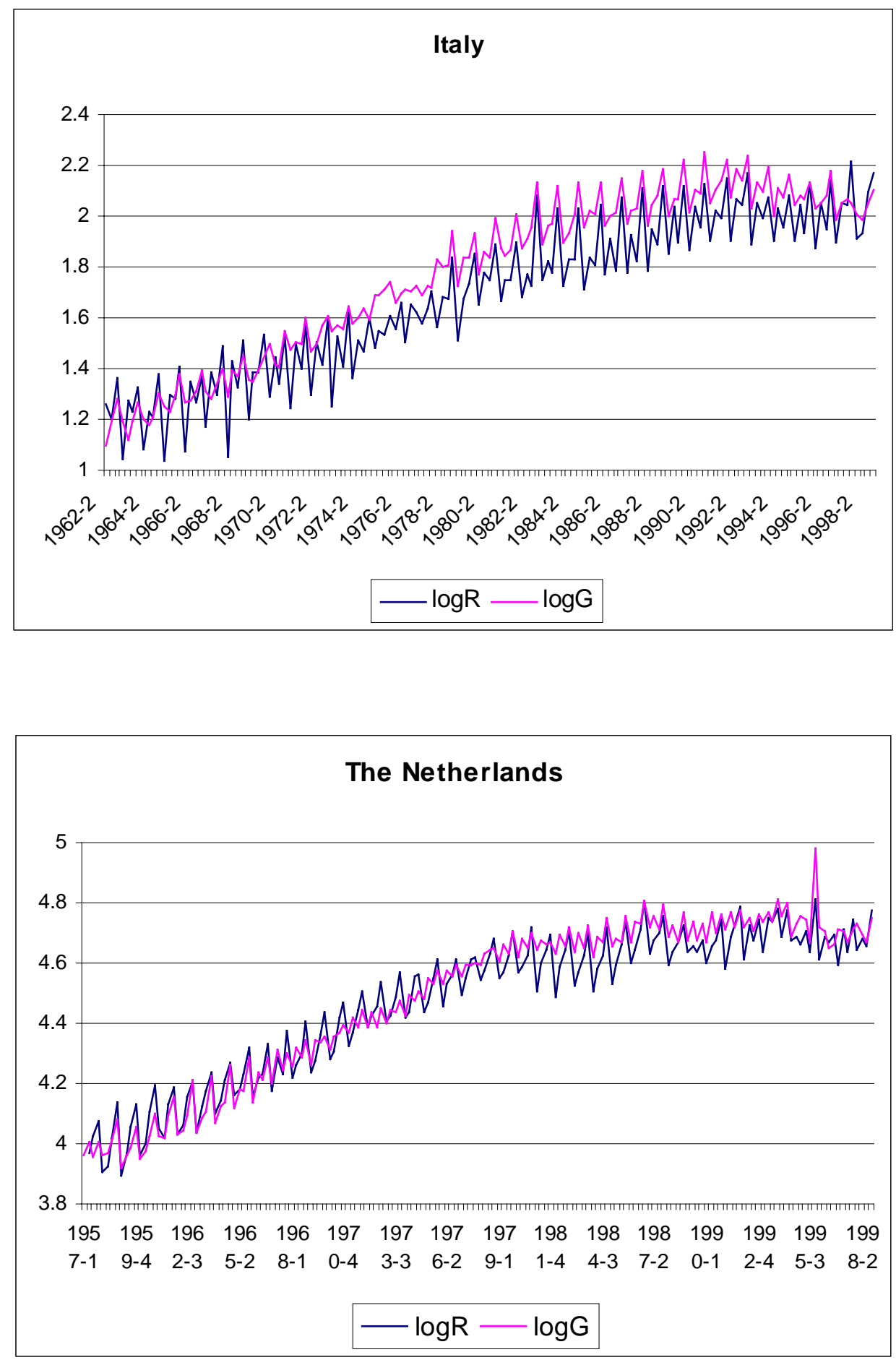
Figure 2 - Sequential Wald tests
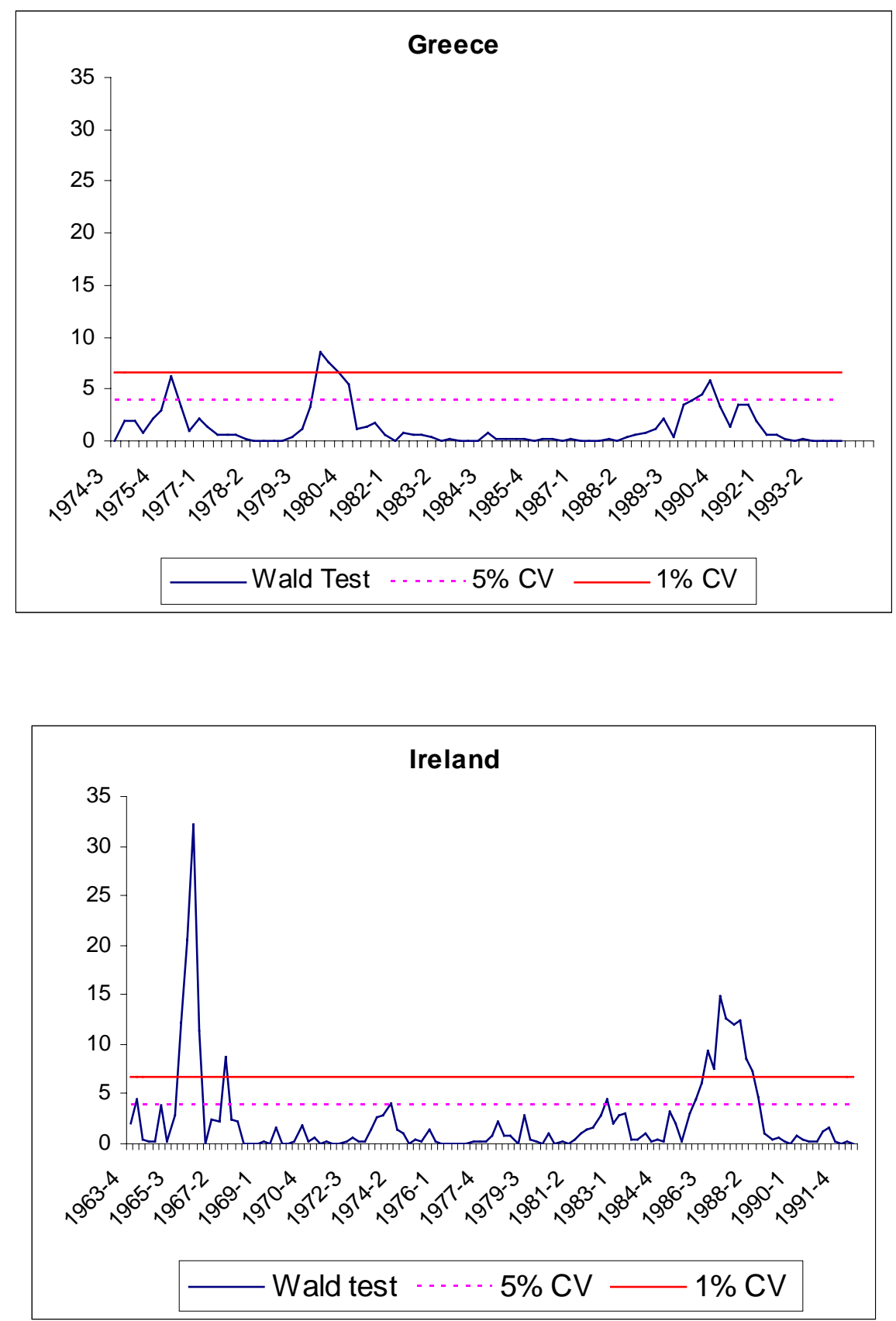

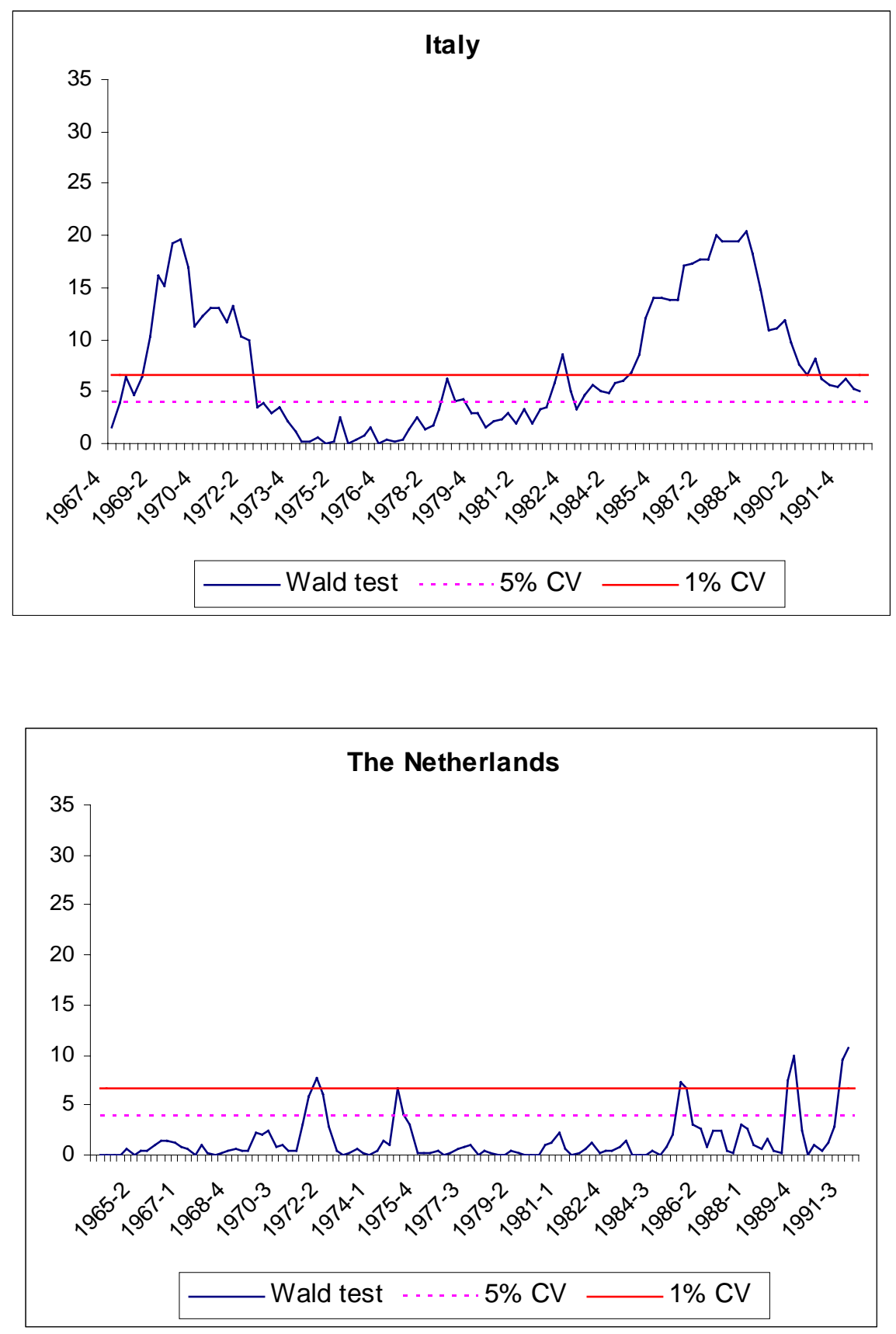

3 


\section{References}

Ahmed S. and Rogers J.H. (1995), "Government budget deficits and trade deficits: Are present value constraints satisfied in long-term data?", Journal of Monetary Economics 36, pp. 351-374.

Alogoskoufis G. (1995), “ The two faces of Janus: Institutions, Policy Regimes and Macroeconomic Performance in Greece”, Economic Policy, 20, pp. 149-192.

Andrews D. W. K. (1993), “Tests for Parameter Instability and Structural Change With Unknown Change Point”, Econometrica, 61, pp. 821-856.

Arestis P., McCauley K. and Sawyer M. (2001), “An alternative to the Stability and Growth Pact”, Cambridge Journal of Economics, January 2001, pp. 113-130.

Arestis P., Khan M. and Luintel K. B. (2002), "Fiscal Deficits in Monetary Unions: A Comparison of EMU and the United States", Eastern Economic Journal 28, pp. 89-103.

Arghyrou M.G. (2000), "Greek macroeconomic policy in the 1990s", in A. Mitsos and E. Mossialos (eds.) Contemporary Greece and Europe, The European Political Economy Series, The LSE European Institute, Ashgate Publishing, pp. 157-180.

Avan Ark B., de Haan J. and de Jong H.J. (1996), "Characteristics of economic growth in the Netherlands during the post-war period", in N. Crafts and Gianni Toniolo (eds.), Economic Growth in Europe since 1945, Centre for Economic Policy Research, London, pp. 290-322.

Bank of Italy (1982), Assemblea Generale Ordinaria Dei Partecipanti Anno 1981, (in Italian).

Bohn H. (1998), “The Behavior of U.S. Public Debt and Deficits”, The Quarterly Journal of Economics 113, pp. 949-963.

Buiter W., Corsetti G. and Roubini N. (1993), "Sense and Non-sense in the Treaty of Maastricht”, Economic Policy 16, pp. 57-100.

Christiano L. J. (1992), "Searching for breaks in GNP", Journal of Business and Economic Statistics 10, pp. 237-250.

Christodoulakis N. (1994), "Fiscal developments in Greece, 1980-93", European Economy No 3/1994, pp. 99-134.

Corsetti G. and Roubini N. (1991), "Fiscal deficits, public debt and government solvency: Evidence from OECD countries", Journal of Japanese and International Economies 5, pp. 354-80. 
Dafflon B. and Rossi S. (1998), "Public Accounting Fudges Towards EMU: A First Empirical Survey and Some Public Choice Considerations", Public Choice 101, pp. 5984.

Dickey D. A. and Fuller W.A. (1979), "Distribution of the Estimators for Autoregressive Time Series with a Unit Root" Journal of American Statistical Association 74, pp. 427431.

Eichengreen B. and Wyplosz C. (1998), "The Stability Pact: more than a minor nuisance?", Economic Policy 26, pp. 67-104.

Giavazzi F. and Pagano M. (1991), "Can severe fiscal contractions be expansionary? Tales of two small European Economies", The NBER Macroeconomics Annual, Cambridge MA: MIT Press

Hakkio C. S. and Rush M. (1991), "Cointegration and Government Borrowing Constraints: Evidence for the United States", Journal of Business \& Economic Statistics 9, pp. 429-445.

Hamilton J. D. and Flavin M.A. (1986), "On the Limitations of Government Borrowing: A Framework for Testing", American Economic Review 76, pp. 808-819.

Haug A. A. (1991), "Cointegration and Government Borrowing Constraints: Evidence for the United States”, Journal of Business \& Economic Statistics, 9, pp. 97-101.

Johansen S. (1988), "Statistical analysis of cointegration vectors", Journal of Economic Dynamics and Control 12, pp. 231-254.

Kremers J. J. M. (1988), "Long-Run limits on the US federal debt", Economics Letters 28, pp. 259-262.

Kwiatkowski, D., Phillips, P., Schmidt, P., and Shin Y. (1992) "Testing the Null Hypothesis of Stationarity Against the Alternative of a Unit Root," Journal of Econometrics 54, pp. 159-178.

Makrydakis S., Tzavalis E. and Balfoussias A. (1999), "Policy regime changes and the long-run sustainability of fiscal policy: an application to Greece", Economic Modelling 16, pp. 71-86.

O'Grada C. and O'Rourke K. (1996), "Irish economic growth, 1945-88", in N. Crafts and Gianni Toniolo (eds.), Economic Growth in Europe since 1945, Centre for Economic Policy Research, London, pp. 388-420.

Perron P. (1997), "Further evidence on breaking trend functions in macroeconomic variables", Journal of Econometrics 80, pp. 355-385. 
Philips P. C. B. and Hansen B. E. (1990), "Statistical Inference in Instrumental Variable Regression With I(1) Processes", Review of Economic Studies, 57, pp. 99-125.

Quintos C. E. (1995), "Sustainability of the Deficit Process With Structural Shifts", Journal of Business \& Economic Statistics 13, pp. 409-417.

Rossi N. and Toniolo G. (1996), "Italy", in N. Crafts and Gianni Toniolo (eds.), Economic Growth in Europe since 1945, Centre for Economic Policy Research, London, pp. 427-450.

Saikkonen P. (1991), "Asymptotically Efficient Estimation of Cointegrating Regressions", Econometric Theory 7, pp. 1-21.

Stock J. and Watson M. (1993), "A Simple Estimator of Cointegrating Vectors in Higher Order Integrated Systems”, Econometrica 55, pp. 1035-1056.

Trehan B. and Walsh C. E. (1988), "Common Trends, the Government's Budget Constraint and Revenue Smoothing", Journal of Economic Dynamics and Control, pp. 425-444.

Trehan B. and Walsh C. E. (1991), "Testing Intertemporal Budget Constraints: Theory and Applications to U.S. Federal Budget and Current Account Deficits", Journal of Money, Credit and Banking, 23, pp. 206-223.

Wilcox D. (1989), "The Sustainability of Government Deficits: Implications of the Present-value Borrowing Constraint", Journal of Money, Credit and Banking 21, pp. 291306.

von Hagen J. and Eichengreen B. (1996), "Federalism, Fiscal Restraints and European Monetary Union", American Economic Review Papers and Proceedings, May, pp. 134138. 